\title{
EMPREENDEDORISMO POR ENGAJAMENTO E SUSTENTABILIDADE PROJETUAL: LEITURA DOS PROCESSOS DOS DESIGNERS EMPREENDEDORES, PELO DESIGN ESTRATÉGICO
}

\author{
Keyla Copes Rodrigues, Mestranda em Design (Unisinos) \\ Carlo Franzato, Dr. (Unisinos)
}

Os designers atuam e empreendem na busca por transformações no mundo. A sustentabilidade é um conceito que os designers-empreendedores frequentemente compartilham nos projetos. Dessa forma, o objetivo geral da pesquisa é compreender a sustentabilidade projetual nos processos elaborados pelos designers-empreendedores. Para isso, foi realizada uma pesquisa exploratória com entrevistas em profundidade com seis designers-empreendedores.

Nas entrevistas, a identificação dos pilares social e ambiental da sustentabilidade dos projetos esteve muito clara, pois os designers apresentam um engajamento com a situação. Entretanto, o pilar econômico não aparece como um dos focos dos entrevistados, considerado imprescindível para a sustentabilidade das organizações e, principalmente, dos projetos assim desenvolvidos. Isso se justifica, pois esse novo perfil de empreendedor, não vislumbra o retorno financeiro do projeto, mas a transformação do mundo no qual está inserido. São empreendedores que buscam formas alternativas para se sustentarem financeiramente, pois acreditam nos seus projetos e, que em algum momento, eles podem ser fonte de sustento. Logo, porém, eles entendem a dificuldade de sustentar seus negócios em um sistema socioeconômico que atribui uma importância secundária a sustentabilidade. Torna-se necessária uma elaboração estratégica que permita uma sustentação em longo prazo, com foco na perenidade desses projetos, que vai além do conceito de sustentabilidade. Surge então o conceito de sustentabilidade projetual, com foco na permanência de um projeto por prazo indeterminado. $O$ termo sustentabilidade projetual é a ação de ser economicamente viável, socialmente justo, ecologicamente correto e projetualmente contínuo. Sustentabilidade projetual é entendido como um conceito no nível meta, sendo a sustentabilidade da sustentabilidade, ou seja, o que sustenta a sustentabilidade.
Dentro deste processo, se vai além da sustentabilidade apenas como aspectos sociais, ambientais e econômicos, mas se cria uma ação projetual no qual a sustentabilidade aparece como fomento para o crescimento, desenvolvimento de projetos, e não apenas como objetivo fim.

Os resultados ainda destacam o conceito de empreendedorismos por engajamento, um novo método de empreender dos designers, diferente dos conceitos já apresentados pela Global Entrepreneurship Monitor - GEM (2015). Ou seja, os entrevistados não apresentam o perfil de empreendedores por necessidade (não são obrigados a empreender para sobreviver) ou por oportunidade (não empreendem em uma oportunidade de mercado cuja relação entre risco e retorno seja claramente vantajosa). De acordo com os resultados do estudo, há um empreendedorismo por engajamento, pois as empresas são criadas por acreditarem na sustentabilidade e por possuírem um envolvimento emocional com base em seus princípios. Diante disso, as ideias com esse conceito surgem do querer fazer, da paixão por um produto ou por um estilo de vida. Desta forma, entende-se que o empreendedor por engajamento é aquele que empreende por querer ver a transformação no mundo, através de seu engajamento com uma causa ou ideal. Sabe-se que há um grande campo de pesquisa, para uma evolução em relação ao conceito aqui apresentado e como ele pode contribuir para o campo do empreendedorismo e do design estratégico.

\section{REFERÊNCIAS}

GEM [Global Entrepreneurship Monitor]. Empreendedorismo no Brasil. Relatório Pesquisa Completa 2015. Disponível em: < http://www.bibliotecas.sebrae.com.br/chronus/ARQUIVOS_CHRONUS/bds/ bds.nsf/4826171de33895ae2aa12cafe998c0a5/\$File/7347. pdf>. Acesso em: 15 março. 2017 